\title{
MODELLING OF THE FUNCTIONAL UNITS OF THE TRANSMITTING AND RECEIVING RADIO PATHS OF TERAHERTZ
}

\author{
Mykhaylo Yu. Ilchenko, Alexey V. Lutchak, Stanislav V. Denbnovetsky, Alexey V. May \\ National Technical University of Ukraine "KPI", Kyiv, Ukraine \\ Theodor M. Narytnik \\ JV "Institute of Electronics and Communication of Ukrainian Academy of Sciences", Kyiv, Ukraine
}

\begin{abstract}
Background. One of the promising applications of terahertz technology are communication systems and telecommunications. In particular, it provides for the creation of fundamentally new in size, noise immunity and energy efficiency devices and subterahertz (TGD) for high-speed transmission of video signals, microwave radio systems, line of sight, the fifth generation of transport of distribution of mobile networks $(5 \mathrm{G})$ and radar for the purpose of high-precision detection and recognition of small high-speed targets. The development of the element base of electronic devices, the widespread introduction of digital technology formation and signal processing allow a new approach to the solution of many problems of telecommunication systems and subTGD. These circumstances make this range unique to the construction of telecommunication systems and networks, including the PPC line of sight for the transport of the fifth generation of mobile networks $(5 \mathrm{G})$. Today there is a great need in the organization of high-reliability single-span lines designed for ultra-fast data transmission and exchange of data between computers and peripheral devices. For these purposes, the most suitable for microwave links TGD, the advantages of which are high noise immunity and bandwidth, low energy consumption. The task of developing the transmitting and receiving paths PPC becomes extremely important.
\end{abstract}

Objective. The aim of the paper is the development of new circuit-technological solutions for creating transmission with high (up to $5 \mathrm{~mW}$ ) output power and receiver (with high sensitivity - noise ratio of $10 \mathrm{~dB}$ ) radiopathes terahertz wavelengths.

Methods. Analysis of all known publications devoted to the design of telecommunication devices and systems and subterahertz range using microwave photonics technology and electronics, made it possible to offer new scheme-technological solutions create a local oscillator on the basis of quasi-optical power and spatial summation methods and a highly sensitive frequency converters pumped the fundamental harmonic

Results. The modeling and experimental studies of functional units receive and transmit paths of the telecommunications system in the terahertz frequency range 130-134 GHz, consisting of: frequency converters pumped to the primary harmonic oscillator using the quasi-optical power and spatial summation methods, band-pass-filter septum waveguide channel 1,6'0,8 mm. For the first time using the proposed scheme and the authors of the new technological solutions developed transmission (with an output power up to $5 \mathrm{~mW}$ ) and the receiver (with a noise figure of $10 \mathrm{~dB}$ ) of the radio terahertz wavelengths.

Conclusions. The created transmission (with an output power up to $5 \mathrm{~mW}$ ) and the receiver (with noise coefficient at $10 \mathrm{~dB}$ ) of the radio terahertz wavelength range can be used in the construction of telecommunication systems and networks, including radio-relay systems, line of sight for the transport of mobile next generation networks . Providing bandwidth radio link in the tens of $\mathrm{Gb} / \mathrm{s}$ or more (required in the future) is possible through the use of terahertz wavelengths, which allows you to not only greater speed of information transmission, but also highly reliable radio communication at a very low weight and envelope transceiver transmitting channel and antenna system.

Keywords: computer modeling terahertz range of the radio transmitter and receiver; frequency converters; quasi-optical local oscillator; septum-filter telecommunication system.

\section{Introduction}

One of the promising applications of tera-hertz technology are communication systems and telecommunications [1]. In particular, it provides for the creation of fundamentally new in size, noise immunity and energy efficiency devices and sub-terahertz (THD) for highspeed transmission of video signals, radio relay systems (RRS) line of sight, traffic distribution of the fifth generation of mobile networks $(5 \mathrm{G})$ and radar for the purpose of precision detection and identification of small highspeed targets.

The development of the element base of electronic devices, the widespread introduction of digital technology formation and signal processing provide a new approach to the solution of many problems of telecommunication systems and sub- THD. These circumstances make this range unique to the construction of telecommunication systems and networks, including the RRS 
line of sight for the transport of the fifth generation of mobile networks $(5 \mathrm{G})$.

In recent years, the trend of using radio waves acquired THD sustainable. This is due to advances in the development of technologically advanced products and systems [2-9], the most important advantage of -which is a wide operating frequency range. The narrow directional diagram (DD) antennas in this band are elevated promote secrecy of communication and suppression of harmful interference, and high rate of amplification, will reduce the transmitter power and improve the weight and size of equipment. Small size and weight of electronic equipment and antenna system THD at high-speed information transmission and secure communications make them more attractive for use in on-board equipment.

Today there is a great need in the organization of high-reliability single-span links for the transmission of multi-channel telephony, as well as the exchange of data between computers and peripheral devices [10-11]. For these purposes, the most suitable for microwave links THD, the advantages of which are high noise immunity and pro-throughput capacity, low energy consumption. The task of developing the transmitting and receiving paths RRS becomes extremely important.

\section{Structural diagram of a transmitter and the receive path}

The key elements are THD RRS communication transceiver radio electronic devices capable of generating and transmitting modulated signals required power at a rate of $1 \mathrm{Gbit} / \mathrm{s}$ and receive signals at an acceptable high sensitivity [10]. The transmitting and receiving paths comprise analog (line) of the RRS. Tract built by heterodyne scheme and provide the transmission of signals on the track in the frequency THD within $130 \ldots$ $134 \mathrm{GHz}$. Intermediate frequency range is $2 \ldots 4 \mathrm{GHz}$.

The block diagram of the transmission path includes: an intermediate frequency amplifier (IFA) (if necessary), the frequency converter up oscillator, band-pass filter (BPF).

On the transmission path from the input signal generator receives radio signals in the group if the signal strength is adequate to obtain the necessary signal level at the converter output, the circuit does not require an intermediate frequency amplifier (IF amplifier).

The block diagram of the receive path consists of an input band-pass filter, mix-telja, local oscillator and intermediate IF amplifier.

Modelling and development of functional units receive and transmit paths [12-13].

Signal frequency converters. Frequency converter up and mixer operating in different modes and different functions, have the same unifying-bathroom design and construction.

Transducers are based on unpackaged GaAs Schottky diodes beamed conclusions. Limiting diodes frequency of $2.5 \mathrm{GHz}$, allows them to work at IU-D in the bottom of the THD. In the electrical and design parameters developed diodes that are not inferior to foreign analogues, such as gallium-arsenide diodes from Hewlett Packard.

\section{Balanced Mixer reception path}

The monolithic integrated circuit-balanced mixer is shown in Fig.1.



Fig.1. Monolithic integrated circuit balanced mixer:

1-slot transmission line; 2-strip conductors (gold thickness $6 \mathrm{mkm}) ; 3$-series two semiconductor diode included;

4-resonator waveguide-slot; 5-strip line; 6-coplanar line forehand chi; 7-night strip of gallium arsenide.

MMIC mixer comprises a slot transmission line (RF), Schottky diodes, the output slot line is connected to a slotted resonator coplanar line (LO) for supplying a local oscillator signal. Land strip line is the output of intermediate frequency (IF) and the element impedance matching the LO input waveguide with Copley nary line.

The strip resonator introduced reactive elements in the form of gallium arsenide strips, which are made in a single technological cycle for MMIC fabrication technology.

Implementation of reactive elements in the form of two strips of gallium-arsenide (capacitive reactance) with a distance equal to half the operating frequency of the central wavelength of the local oscillator can further expand the bandwidth of the resonator bandwidth, due to the emergence of new capacitive coupling while maintaining a sufficiently large level of merit.

When submitting information to the slot line of RF electromagnetic wave signal is spread over a slot line, excite the resonator and semiconductor diodes opposite phase. LO signal propagating through the strip and coplanar transmission line resonator and excites the slotphase semiconductor diodes. Semiconductor diodes conversion performed two oscillation frequencies and the intermediate frequency difference signal $\mathrm{Fpch}=\mathrm{fg}$ - 
fc is removed from the strip line and provided to bandpass filter the intermediate frequency (not shown).

Dimensions MMIC BS 3,81 × 1,24 × 0,007 mm. Broadband BS receiver HF made by the technology of manufacturing gallium arsenide MMIC and are characterized by a low level of spurious links. The introduction of reactive elements in the cavity in the form of gallium arsenide strips, made in a single technological cycle of production of MMIC, allows you to get rid of these parasitic phenomena such as "seepage" of electromagnetic radiation on the dielectric substrate, to reduce to a minimum parasitic coupling.

The design of such BS (Fig.2) consists of halves cut by E-plane waveguide is $1.6 \mathrm{~mm} \times 0.8 \mathrm{MMIC}$ and one of them made in a unitary structure.

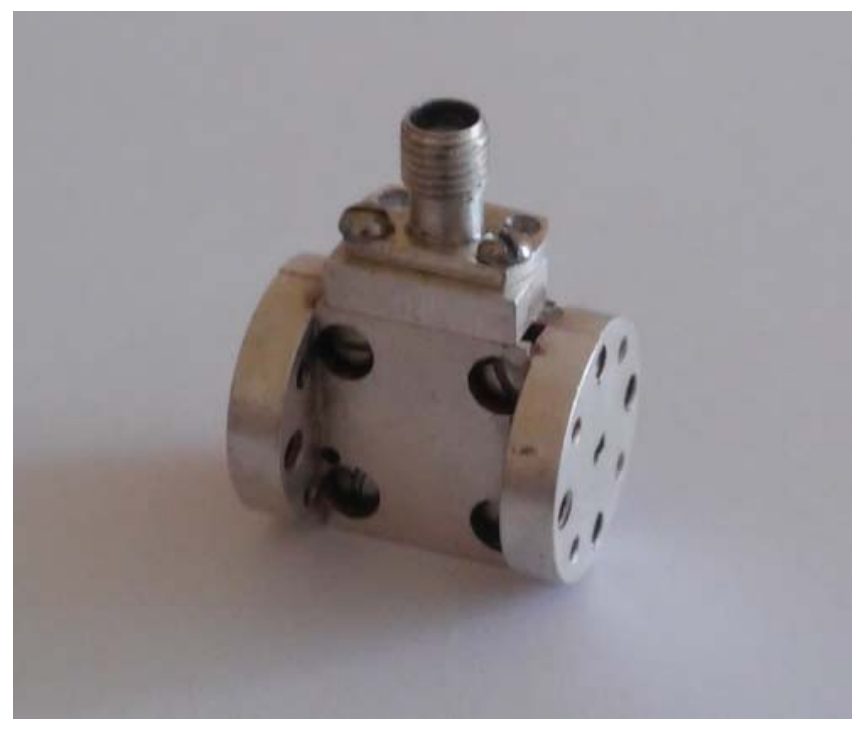

Fig.2. Appearance balanced mixer

The measured conversion loss (SSB) BS is $8 \mathrm{~dB}$, which corresponds to the best foreign analogues.

\section{Drive up}

Raising the frequency converters or shear mixers are designed to convert the IF signal into higher frequencies.

A transmitter mixer feature is sufficiently large input signal levels and local oscillator oscillation, and hence the conversion side products.

The main requirements to the mixer of the transmitter are: to provide a specified output power with a valid non-uniformity in the range of operating frequencies, given the suppression of side conversion products, low conversion loss, stability, reliability, maximum capacity factor oscillator (the ratio of power you-output signal to the power oscillator ).

The requirement of maximum capacity utilization heterodyne or otherwise efficiency, it is important for the transmitter, because mixer latter operates at a relatively high signal level (up to tens of milliwatts).

Hybrid integrated circuit (GIS) of the mixer has a slot transmission line, one end of which is the input information signa la. On the other hand the topological scheme is coplanar transmission line LO. In the AA, the gap slotted and coplanar transmission lines in seriesparallel include four planar Schottky diode mixer (Fig.3).

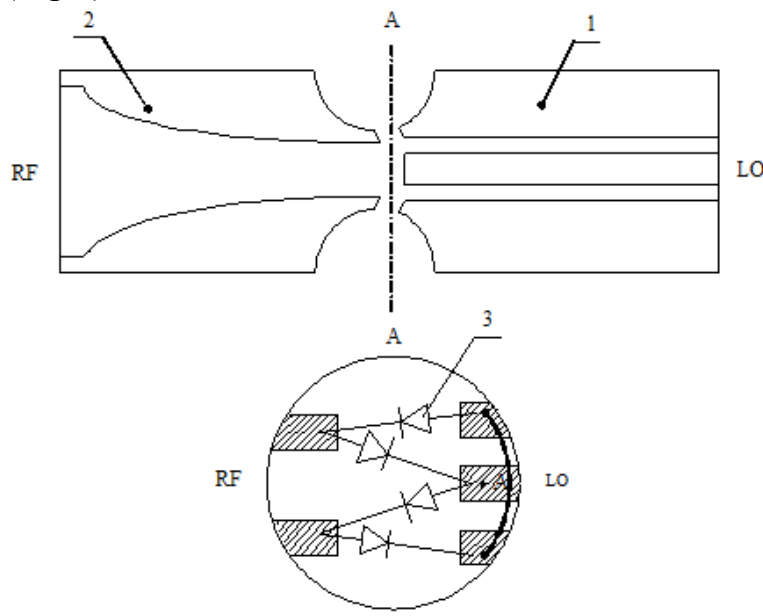

Fig. 3. The hybrid-integrated shear mixer circuit: 1 - coplanar line; 2 - waveguide-slot line; 3 - Schottky diodes

When applying to the input slot line information signal HF, electromagnetic waves excite the semiconductor diodes anti-phase. LO signal propagating through the coplanar transmission line excites semi-phase-conductor diodes. In the semiconductor diode is made the conversion of the two oscillation frequencies and the difference signal of the intermediate Fpch frequency $\mathrm{fg}=-\mathrm{fc}$ is removed from the main strip of the coplanar line (point A, see Fig.3.) And fed to an intermediate frequency filter (not shown in Fig.).

In modern microassemblies hybrid integrated circuits play the important role in the installation technologies. Mounting diodes done by bonding directly to a substrate of duroid.

Designed shear mixer based on GIS has the following parameters: Working part-ta transmitter signal $\mathrm{GHz}$ 134; The operating frequency of the LO signal $\mathrm{GHz}$ 129.6; Decoupling the local oscillator signal, dB - 25.0; LO-IF Isolation $\mathrm{dB}$ - 30.0; The output power at compression gain by $1 \mathrm{~dB}, \mathrm{dBm}$ : power at $13 \mathrm{dBm}$ LO ... $10-$ 5.0; when power bi-din $13 \ldots 15 \mathrm{dBm}$ - 9.0; Intermediate frequency range, $\mathrm{GHz}-2.0-4.0$; The conversion losses, $\mathrm{dB}-8.0$.

From the analysis of the characteristics we can conclude that the power of the transmitter locat-ditsya within 3-5 MW, which is sufficient for communication transmission / reception on interviews le ... $1.05 .0 \mathrm{~km}$. 


\section{Local oscillator with a usage of quasi-optical and spatial summation methods of power}

Quasi-optical power and spatial summation of techniques have been developed to overcome the main drawbacks of solid-state devices, such as low power level, the lack of frequency stability in the short-wave part of the millimeter-wave and terahertz wavelengths. Since the transmission line used for circuit integ ation (microstrip, and coplanar slotted) lose their advantages in these frequencies due to radiation losses, the losses in the substrate and ohmic losses, the effective power of the summation must be performed in free space.

The most promising in the terahertz range are open resonators (OR) hemispherical geometry. A hemispherical resonator re-formed flat and spherical mirrors. Estimated distribution of the first phase of the higher type of oscillations in an open resonator is shown in Fig.4.

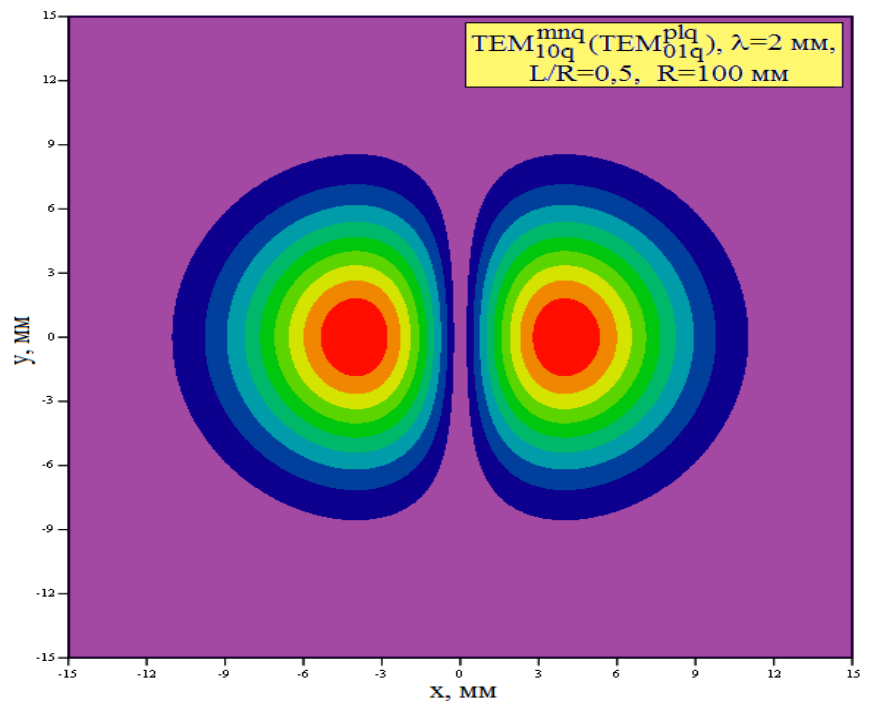

Fig.4. The phase distribution of the first higher-type oscillations in the open resonator.

It was experimentally studied at a frequency of 130 $\mathrm{GHz}$, OR with fluctuations TEM10q type that is driven by two frequency multipliers and two planar aperture coupling elements ensures consistency, both in amplitude and phase [12], [13].

Aperture coupling element in the form of a strip line and slotted planar horn, realized on the dielectric material duroid $58800.127 \mathrm{~mm}$ thick.

The main advantage of coupling element is that it allows you to separate the functions of coordination on the field and Communications. Since the geometric dimensions of the aperture coupling element exceeds the length of the working wavelength oscillation of the resonator, it will eliminate the power loss due to the diffraction of the wave beam on it. It also significantly reduced non-resonant background.
The distance between the centers of the spots field is $10,5 \mathrm{~mm}$. This distance is an inter-element gap inclusion in the OR circuit frequency multiplier and a planar aperture coupling element.

Dimensions mirrors PR always define a spherical mirror, because the size of the spots field oscillations it is always greater than in the flat.

We define the ratio of length to the radius of curvature of the $\mathrm{L} / \mathrm{R}=0,5, \mathrm{R}=100 \mathrm{~mm}, \lambda=2,2 \mathrm{~mm}, \mathrm{~L}=50$ $\mathrm{mm}$, then the radius of the fundamental oscillation field spots on the spherical mirror TEM $10 \mathrm{q}$ is $8.5 \mathrm{~mm}$, the diameter of the mirror $45 \mathrm{~mm}$, the effectiveness of PR $\eta$ $=0,867$ [14-15].

Dimensions in the screen OR: diameter - $40 \mathrm{~mm}$; length - $55 \mathrm{~mm}$.

The measured output power levels with ER receiver outputs and transmitter is $13 \ldots 15 \mathrm{dBm}$. These power levels are sufficient for normal operation of the BS transmitter and the receiver transmitter up.

\section{Structural scheme of heterodyne chain}

As an example of a local oscillator using quasioptical and spatial summation power output part methods consider heterodyne circuit. The input of the heterodyne circuit consisting of a master crystal oscillator at $100 \mathrm{MHz}$ and a number of intensive-of multiplying chains formed on monolithic chips are not regarded in detail, as it is implemented in the normal way.

The frequency of the signal which is input from the preliminary circuits heterodyne circuit stages is increased to $32.4 \mathrm{GHz}$ through two series-connected doublers performed on 2089 chips CHX UMS and XX company BD company 1000 Mimix Broadband (Fig.5). These chips have built-in amplifiers to compensate for signal loss when multiplied.

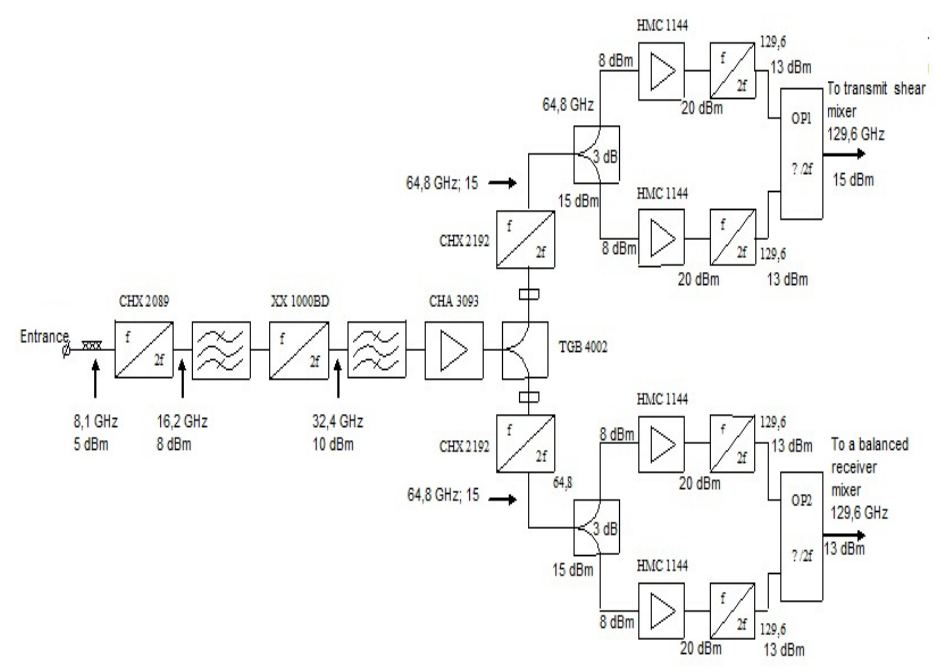

Fig.5. Block diagram of the output of the heterodyne Chain 
Band-pass filter at the output of multiplying stages helps prevent spurious harmonics to the inputs of the subsequent stages. To obtain an adequate level of output power to the coupler incorporated power amplifier, which is implemented on a chip CHA 2093 firmy UMS.

The amplified signal frequency of $32.4 \mathrm{GHz}-1$ jaetsja ramified into two channels. The multiplier output stage is built on chips CHX 2192 company UMS. Bifurcation is performed on the chip firm TGB 4002 TriQuint.

Monolithic chip multipliers power amplifier and the tap signals included in the microstrip line on the substrate of duroid $0.127 \mathrm{~mm}$ thick.

Signals frequency of $64.8 \mathrm{GHz}$ and a power of 13 $\mathrm{dBm}$ received by $3 \mathrm{~dB}$ couplers and share power in half.

To obtain a sufficient power level at the input of the frequency multiplier, the signals are fed to power amplifiers which are formed on chips NMS firm Analog Devices 1144 and amplified to levels of $80-100 \mathrm{~mW}$.

Further increase of the local oscillator frequency from $64.8 \mathrm{GHz}$ to $129.6 \mathrm{GHz}$ frequency doubler is performed. Frequency multipliers are built on the basis of multiplying packageless planar Schottky diodes.

The measured power levels output frequency doublers $20 \ldots 25 \mathrm{~mW}$.

Two signal frequency $129.6 \mathrm{GHz}$ and a power of 20 ... $25 \mathrm{~mW}$ are summed up in an open resonator (OR).

OR possesses selective properties and suppresses harmonics and spurious frequency multiplier 50 frequency $\mathrm{dB}$ or more.

The measured output power levels are within the cavities $13 \ldots 15 \mathrm{dBm}$.

In operation for circuit simulation (mixers, multipliers, amplifiers, dividers) used software package NI AWR Design Environment; filters, waveguide structures - ANSYS HFSS, resonators - Altair FEKO.

\section{Extremely high frequency band-pass filter}

EXTREMELY bandpass filters (PPF) at the output of the transmitter and the receiver input paths should provide time-mating signal paths of data, as well as a sufficient suppression of the mirror channel and local oscillator signals. Low IF $(\mathrm{Fpch}=1 \ldots 3 \mathrm{GHz})$ stipulates strict requirements for high frequency SMA on selectivity. The most acceptable in a $2-\mathrm{mm}$ wavelength range from the viewpoint of low losses and high selectivity is a wave-septum-water filters. Such a filter has been developed within the project.

Structurally, the filter is a thin metal plate inserted in the E plane of the waveguide channel. The plate includes a resonance box, the relationship between them is determined by dividing the width of the strips. To ensure sufficient selectivity taken six-resonator filter. Calculate the size of the insert plate with the resonance windows are shown in Fig. 6.

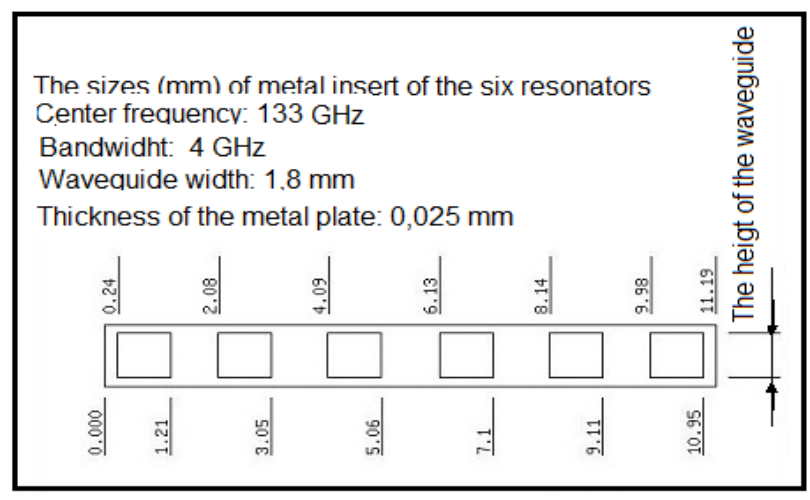

Fig. 6. Configuration and dimensions of a metal insert that can be housed in the E-plane waveguide channel

Fig. 7 shows the calculated S-parameters sixresonator PPF and its frequency response. The experimental results show that the filter meets the selectivity necessary to provide sufficient reduction (over $20 \mathrm{~dB}$ ) and a second mirror channel local oscillator harmonic $(129.6 \mathrm{GHz})$.

Losses in the filter THD transmitter do not exceed 4 $\mathrm{dB}$, which is a satisfactory result for such high frequencies. Flatness on the flat portion is less than $2 \mathrm{~dB}$.

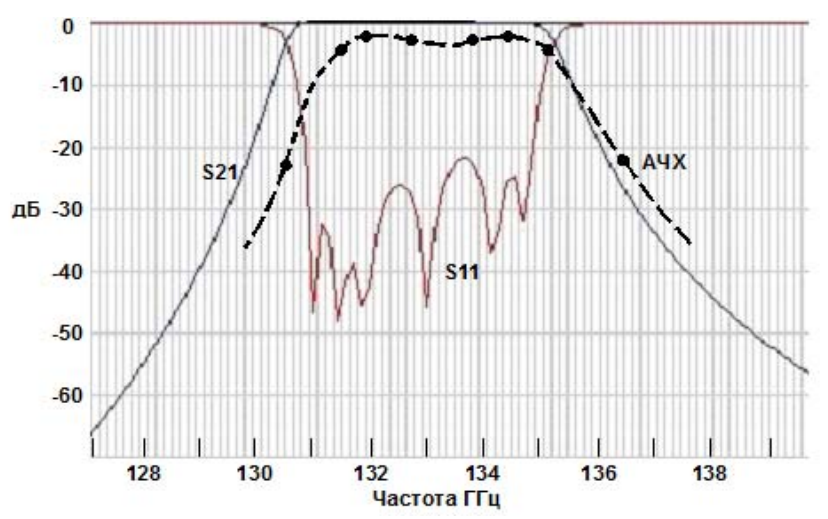

Fig. 7. The calculated S-parameters and measured AFC septum filter.

\section{Conclusion}

The created transmission (with an output power up to $5 \mathrm{~mW}$ ) and the receiver (with noise coefficient at $10 \mathrm{~dB}$ ) of the radio terahertz wavelength range can be used in the construction of telecommunication systems and networks, including radio-relay systems, line of sight-sti for the transport of mobile networks after blowinggeneration. Providing bandwidth of the radio link capacity of tens of Gbit / s or more (in need in the future) probably due to use of terahertz wavelength range, which provides not only high speed of information transmission, but also highly reliable radio communication at a very low weight and envelope transceiver and antenna system tract. 


\section{References}

1. S.O. Kravchuk Terahertz range telecommunication systems / Kravchuk S.O., Naritnik T.M. // Zhytomyr: sole proprietor "Evenok O.O.", 2014. - 394 p.

2. M.Ye. Ilchenko Transceiver for 130-134 GHZ band and digital radiorelay system / Ilchenko M.Ye., Narytnik T.N., Kuzmin S.Ye. // Telecommunications and Radio Engineering. - 2013. - Vol. 72, №17. -P.1623-1638.

3. M.Ye. Ilchenko Modelling of functional nodes of terahertz range radiorelay system / Ilchenko M.Ye., Narytnik T.N., Kuzmin S.E., Radzikhovskiy V.N. // Problems of telecommunications. - 2013. - №2 (11). - P. 95-113.

4. M.Ye. Ilchenko Transceiver for digital radiorelay system of terahertz range / Ilchenko M.Ye., Kuzmin S.E., Narytnik T.N., Radzikhovskiy V.N. // Telecommunication Science. - 2013. - Vol. 72, - №18. - P.1651-1663.

5. M.Ye. Ilchenko Modelling of functional nodes of terahertz range radiorelay system / Ilchenko M.Ye., Kuzmin S.E., Narytnik T.N., Radzikhovskiy V.N. // Problems of telecommunications. - 2013. - №2 (11). - P. 95-113.

6. M.Ye. Ilchenko Transceiver for digital radiorelay system of terahertz range / Ilchenko M.Ye., Kuzmin S.E., Narytnik T.N., Radzikhovskiy V.N. // Materials of the 23rd International Crimean Conf. "Microwave equipment and telecommunication technologies". - 2013. - Vol.1. - P.318-319.

7. T.N. Narytnik, M.Ye. Ilchenko, V.N. Radzikhovskiy radio communication research for advanced telecommunications systems of terahertz range / Narytnik T.N., Ilchenko M.Ye., Radzikhovskiy V.N./// Materials of the 8th International Scientific and Engineering. Conf. "Problems of telecommunication". - Kyiv: NTUU “KPI”, 2014 - P.137-140.

8. M.Yu. Ilchenko, T.N. Narytnyk, V.Ya. Kazimirenko, O.G. Voitenko, V.V. Radzikhovskiy, V.V. Sviridenko Two- way information flow generator for the channel with increased spectral efficiency and throughput. Patent of Ukraine for utility model №84923 dated from 25.11.2013, Bul.№21.

9. M.Yu. Ilchenko, T.N. Narytnyk, V.Ya Kazimirenko, V.V. Radzikhovskiy, S.E. Kuzmin Data transmission channel in terahertz range with bandwidth of more than $1 \mathrm{Gbit} / \mathrm{s}$. Patent of Ukraine for utility model №93139 dated from 14.10.2014., Bul.№8.

10. T.N. Narytnik Possibilities of Using THz-Band Radio Communication Channels for Super High-Rate Backhaul // Telecommunications and Radio Engineering. - 2014. - №73 (15). - P.1361-1371.

11. V.V. Butenko The path of development of broadband access in Russia / Butenko V.V., Veerpalu V.E., Volodina E.E., Deviatkin E.E. // Telecommunications. - 2014. - №10.

12. A.V. May The integrated receiver of pseudo-optical band / May A.V., Denbnovetsky S.V. // Coll. Of articles of KPI, 2016.

13. M.G. Chausov, O.V. May, Ol-r. V. Mai, O.G. Kirichenko Open resonator. Patent of Ukraine №93745 C2, 2011, Bul. №5.

14. I.K. Kuzmichev Exitation efficiency of qua-sioptical resonance systems / I.K. Kuzmichev // Tele-communications and Radio Engineering. - 2009. - Vol. 68, - No. 1. - P. 49-63.

15. H. Kogelnik Coupling coefficients and the coefficient of the wave transformation coefficients in the optical systems / Kogelnik H./ Trans. from English and German edited by Katsenelenbaum B.Z. and Shevchenko V.V. // Quasioptics. Moscow: Mir, - 1966. - P. 210-225.

Received in final form on June 12, 2016

Ільченко М.Ю., Лутчак О.В., Денбновецкий С.В., Май А., Наритник Т.Н.

Моделювання функціональних вузлів передавального і приймального радіотрактів терагерцового діапазону

Проблематика. Однією з перспективних сфер застосування терагерцових технологій є системи зв'язку. Зокрема, передбачається створення принципово нових за габаритами, завадозахищеністю і енергоефективністю пристроїв суб-і терагерцового діапазону (ТГД) для високошвидкісної передачі відеосигналу, радіорелейних систем прямої видимості, транспортних розподільних мереж мобільного зв'язку п'ятого покоління (5G) i радарів з метою високоточного виявлення і розпізнавання малорозмірних швидкісних цілей. Розвиток елементної бази радіоелектронних пристроїв, широке впровадження цифрової техніки формування і обробки сигналів дозволяють по-новому підійти до вирішення багатьох завдань телекомунікаційних систем суб-і ТГД. Зазначені обставини роблять цей діапазон унікальним для побудови телекомунікаційних систем і мереж, в тому числі РРС прямої видимості для транспортних мереж мобільного зв'язку п'ятого покоління (5G). Сьогодні виникла велика потреба в організації високонадійних однопроглітних ліній зв'язку, призначених для надшвидкісної передачі інформації, а також обміну даними між ЕОМ і периферійними пристроями. Для цих цілей в найбільшій мірі підходять радіорелейні лінії ТГД, перевагами яких є висок завадозахищеність і пропускна здатність, мале споживання енергії. Завдання розробки передавального і приймального трактів РРС стає надзвичайно актуальною.

Мета досліджень. Розробка нових схемно-технологічних рішень для створення передавальних 3 підвищеною (до 5 мВТ) вихідною потужністю і приймальних (з підвищеною чутливістю - коефіцієнтом шуму на рівні 10 дБ) радіотрактів терагерцового діапазону довжин хвиль.

Методика реалізації. Аналіз всіх відомих публікацій, присвячених проектуванню телекомунікаційних пристроїв $\mathrm{i}$ систем суб-і терагерцового діапазону з використанням технологій фотоніки та мікрохвильової електроніки, дав можливість запропонувати нові схемно-технологічні рішення створення гетеродина на основі квазіоптичних і просторових методів підсумовування потужності і більш високочутливих частотних перетворювачів з накачуванням на основній гармоніці

Результати досліджень. Виконано моделювання та експериментальні дослідження функціональних вузлів приймального і передавального трактів телекомунікаційної системи в терагерцевому діапазоні частот 130-134 ГГц у складі: 
частотні перетворювачі з накачуванням на основній гармоніці, гетеродин з використанням квазіоптичних і просторових методів підсумовування потужності, смугопроникний septum-фільтр в в хвилеводному каналі 1,6х0,8 мм. Вперше 3 використанням запропонованих авторами нових схемно-технологічних рішень створені передавальні (з вихідною потужністю до 5 мВт) і приймальні (з коефіцієнтом шуму на рівні 10 дБ) радіотракти терагерцового діапазону довжин хвиль.

Висновки. Створені передавальні (з вихідною потужністю до 5 мВт) і приймальні (з кеффіціента шуму на рівні 10 дБ) радіотракти терагерцового діапазону довжин хвиль можуть бути використані при побудові телекомунікаційних систем і мереж, в тому числі радіорелейних систем прямої видимості для транспортних мереж мобільного зв'язку наступного покоління . Забезпечення пропускної здатності радіолінії в десятки Гбіт/с і більше (потрібно в майбутньому) можливо за рахунок використання терагерцового діапазону довжин хвиль, в якому можна отримати не тільки велику швидкість передачі інформації, але і високу надійність радіолінії зв'язку при досить малій вазі і габаритах прийомо- передавального тракту і антенної системи.

Ключові слова: комп'ютерне моделювання, терагерцовий діапазон, приймальний і передавальний радіотракт, частотні перетворювачі, квазіоптичний гетеродин, septum-фільтр, телекомунікаційна система.

\section{Ильченко М.Е., Лутчак А.В., Денбновецкий С.В., Май А.В., Нарытник Т.Н.}

Моделирование функциональных узлов передающего и приемного радиотрактов терагерцового диапазона

Проблематика. Одной из перспективных сфер применения терагерцовых технологий являются системы связи. В частности, предусматривается создание принципиально новых по габаритам, помехозащищенности и энергоэффективности устройств суб- и терагерцового диапазона (ТГД) для высокоскоростной передачи видеосигналов, радиорелейных систем прямой видимости, транспортных распределительных сетей мобильной связи пятого поколения (5G) и радаров с целью высокоточного обнаружения и распознавания малоразмерных скоростных целей. Развитие элементной базы радиоэлектронных устройств, широкое внедрение цифровой техники формирования и обработки сигналов позволяют поновому подойти к решению многих задач телекоммуникационных систем суб- и ТГД . Указанные обстоятельства делают этот диапазон уникальным для построения телекоммуникационных систем и сетей, в том числе РРС прямой видимости для транспортных сетей мобильной связи пятого поколения (5G). Сегодня возникла большая потребность в организации высоконадежных однопролетных линий связи, предназначенных для сверхскоростной передачи информации, а также обмена данными между ЭВМ и периферийными устройствами . Для этих целей в наибольшей степени подходят радиорелейные линии ТГД, достоинствами которых являются высокие помехозащищенность и пропускная способность, малое потребление энергии. Задача разработки передающего и приемного трактов РРС становится чрезвычайно актуальной.

Цель исследований. Разработка новых схемно-технологических решений для создания передающих с повышенной (до 5 мВт) выходной мощностью и приемных (с повышенной чувствительностю - коэффициентом шума на уровне 10 дБ) радиотрактов терагерцового диапазона длин волн.

Методика реализации. Анализ всех известных публикаций, посвященных проектированию телекоммуникационных устройств и систем суб- и терагерцового диапазона с использованием технологий фотоники и микроволновой электроники, дал возможность предложить новые схемно-технологические решения создания гетеродина на основе квазиоптических и пространственных методов суммирования мощности и более высокочувствительных частотных преобразователей с накачкой на основной гармонике

Результаты исследований. Выполнены моделирование и экспериментальные исследования функциональных узлов приемного и передающего трактов телекоммуникационной системы в терагерцовом диапазоне частот 130-134 ГГц в составе: частотные преобразователи с накачкой на основной гармонике, гетеродин с использованием квазиоптических и пространственных методов суммирования мощности, полосно-пропускающий septum-фильтр в волноводном канале $1,6 \times 0,8$ мм. Впервые с использованием предложенных авторами новых схемно-технологических решений созданы передающие (с выходной мощностью до 5 мВт) и приемные (с коэффициентом шума на уровне 10 дБ) радиотракты терагерцового диапазона длин волн.

Выводы. Созданные передающие (с выходной мощностью до 5 мВт) и приемные (с кэффициентом шума на уровне 10 дБ) радиотракты терагерцового диапазона длин волн могут быть использованы при построении телекоммуникационных систем и сетей, в том числе радиорелейных систем прямой видимости для транспортных сетей мобильной связи следующего поколения. Обеспечение пропускной способности радиолинии в десятки Гбит/с и более (потребуется в будущем) возможно за счет использования терагерцового диапазона длин волн, в котором можно получить не только большую скорость передачи информации, но и высокую надежность радиолинии связи при весьма малом весе и габарите приемо-передающего тракта и антенной системы.

Ключевые слова: компьютерное моделирование, терагерцовый диапазон, приемный и передающий радиотракты, частотные преобразователи, квазиоптический гетеродин, septum-фильтр, телекоммуникационная система. 